\title{
CHANGES IN THE MICROBIOLOGICAL AND PHYSICOCHEMICAL CHARACTERISTICS OF SERRANO CHEESE DURING MANUFACTURE AND RIPENING
}

\author{
Claucia Fernanda Volken de Souza; Tiziano Dalla Rosa; Marco Antônio Zachia Ayub*
}

BiotecLab, Instituto de Ciência e Tecnologia de Alimentos, Universidade Federal do Rio Grande do Sul, Porto Alegre, RS, Brasil.

Received: October 21, 2002; Returned to Authors: May 22, 2003; Approved: July 08, 2003

\begin{abstract}
Changes in the microbial flora present in six Serrano cheese batches (3 ripened in Summer and 3 in Winter) were studied during production and ripening, to microbiologically characterize this cheese, which is traditionally manufactured by farmers in the south of Brazil, using raw cow milk, without the addition of starter cultures. The levels of several microbial groups were enumerated in the milk, curd and different stages of the 60-day long ripening period. Values of some physicochemical parameters, such as $\mathrm{pH}$, titratable acidity, water activity, moisture and $\mathrm{NaCl}$ content were also determined. The correlation coefficients between these parameters and the microbial groups throughout ripening were determined. The influence of the season of the year was also studied. Results demonstrated that the microflora and the physicochemical characteristics of Serrano cheese changed significantly during the 60-day ripening period, especially in Summer. Almost all microbial groups reached their highest counts after the $7^{\text {th }}$ day of maturation, steadily decreasing towards the end of the process. Higher microbial counts during the first week of ripening was accompanied by lactic acid production and, as a consequence, a sharp drop in the $\mathrm{pH}$ of cheese was observed. Lactic acid bacteria comprised the main microbial group present in Serrano cheese and their counts were similar to the total viable counts at all sampling points. The abundance of lactobacilli during the manufacture and ripening suggests that these microorganisms may play an important role in the production of Serrano cheese. In conclusion, this work shows the importance of ripening time being longer than 30 days to allow for microbiological stabilization of this artisanal product. Also, except for halotolerants and moulds counts, and for moisture content, there were no significant differences observed either for microbial counting or for physicochemical characteristics of the cheese concerning the season of the year in which the product was manufactured.
\end{abstract}

Key words: Serrano cheese, cheese ripening, food microbiology, lactic acid bacteria.

\section{INTRODUCTION}

As food markets expand and diversify, there is a growing interest in traditional dairy products manufactured at the farm level due to the uniqueness of such foods and the difficulties in mimicking them on an industrial scale. Serrano cheese, produced in the highlands of Rio Grande do Sul, south of Brazil, is a small scale industrial product with high acceptance by the consumer.

There is very little information available on the microbiology and physicochemical characteristics of artisanal Brazilian cheese. Presently, only the Minas cheese has been studied
$(14,15)$. Serrano cheese is a farm-made variety manufactured from raw milk, in a region located in an altitude of $950 \mathrm{~m}$ above sea level and the average temperatures range from $4^{\circ} \mathrm{C}$ to $13^{\circ} \mathrm{C}$ in winter and from $18^{\circ} \mathrm{C}$ to $26^{\circ} \mathrm{C}$ in Summer.

Serrano cheese is an uncooked, semihard product, with a strong flavour. Its rind is thin, uniform and smooth, with a soft straw-yellow colour and the cheese bulk has a whitish colour with irregularly distributed holes. It is consumed after a short period of ripening, usually 30 days, although the present Brazilian regulation on food safety for cheeses made from raw milk states a minimum ripening period of 60 days prior to consumption (5).

*Corresponding author. Mailing address: BiotecLab, Instituto de Ciência e Tecnologia de Alimentos, Universidade Federal do Rio Grande do Sul. Av. Bento Gonçalves, 9500. 91540-000, Porto Alegre, RS, Brasil. Tel.: (+5551) 3316-6685. E-mail: mazayub@ufrgs.br 
Although Serrano cheese is highly appreciated and consumed, its microbial flora and physicochemical characteristics are unknown. Such lack of knowledge is particularly critical, specially the microbiological quality, because this cheese is manufactured with raw milk and no commercial starters are used in its manufacture, fermentation occurring, therefore, by a natural process. Ripening depends entirely on natural microflora. These artisanal techniques, which include the use of raw milk, acidification by the indigenous lactic acid bacteria present in milk and absence of control of temperature and relative humidity in the maturation room, result in a lack of uniformity and quality of the final product.

The knowledge of microbiological and biochemical reactions in cheese can help to introduce process modifications necessary to improve the quality of products, without any loss in its characteristics. The aims of the present study were to investigate the changes in levels of the main microbial groups and in the physicochemical characteristics throughout the ripening process of Serrano cheese and the influence of the season of the year over these interactions. It is expected that this study will contribute to the establishment of microbiological quality standards for Serrano cheese, as well as to provide further scientific basis for the understanding of ripening process, which is necessary to improve farmhouse procedures.

\section{MATERIALS AND METHODS}

\section{Cheese manufacturing}

Serrano cheese is manufactured according to the following procedure. Whole raw milk is filtered and salted with $4-18 \mathrm{~g} \mathrm{NaCl}$ per litre of milk. Coagulation takes place at an average temperature of $35^{\circ} \mathrm{C}$ for $60-75 \mathrm{~min}$ by adding $4 \mathrm{~g}$ of commercial calf rennet (1: 65000 strength) per litre of milk. Once the right degree of consistency is attained, the curd is cut and the whey is drained at $35-37^{\circ} \mathrm{C}$. Then, the curd is transferred into perforated plastic molds following whey drainage for $24 \mathrm{~h}$ under pressure. Cheeses are allowed to mature without any temperature or humidity control, with variables changing only with year season, in a special maturing house. During ripening they are inverted daily and washed with warm water once a week, with ripening lasting for as long as 30 days. Approximately $10 \mathrm{~L}$ milk are used to obtain flat-cylinder shaped cheeses with $14-17 \mathrm{~cm}$ of diameter, $4-7 \mathrm{~cm}$ high and weighing around $800-1200 \mathrm{~g}$.

\section{Sampling}

Six batches of Serrano cheese manufactured in three different dairies by experienced cheese makers following the traditional method, as described above, were studied. Three were manufactured in Summer (January), the others in winter (July). For every batch, milk, curd and cheeses of 7, 14, 28, 42 and 60 days of maturation were analyzed. Each sample consisted of one whole cheese. Sampling was performed according to
International Dairy Federation (IDF) Standard 50B (18). All samples were transported to the laboratory under refrigeration at $4^{\circ} \mathrm{C}$ and analyzed on arrival.

\section{Microbiological analysis}

Representative $25 \mathrm{~g}$ curd or cheese samples were homogenized with $225 \mathrm{~mL}$ of a sterile $2 \%(\mathrm{w} / \mathrm{v}$ ) sodium citrate solution, previously warmed to $45^{\circ} \mathrm{C}$, in a Stomacher Lab-Blender 400 (Seward Medical, England) for $1 \mathrm{~min}$. Decimal dilutions were prepared in $90 \mathrm{~mL}$ of sterile $0.1 \%(\mathrm{w} / \mathrm{v})$ peptone water and aliquots were plated in duplicate on a variety of media. Total viable count (TVC) and psychrotrophics were made on plate count agar incubated at $32^{\circ} \mathrm{C}$ for $48 \mathrm{~h}$ and $7^{\circ} \mathrm{C}$ for 10 days, respectively. Lactobacilli were enumerated on Rogosa agar acidified to $\mathrm{pH}$ 5.4 with acetic acid after incubation at $30^{\circ} \mathrm{C}$ for 5 days in an anaerobic jar (Oxoid, Unipath Ltd., Basingstoke, England) with anaerobiose produced by Anaerocult A (Merck, Darmstadt, Germany). Lactococci were determined on M17 agar incubated at $30^{\circ} \mathrm{C}$ for $72 \mathrm{~h}$. Proteolytic and lipolytic organisms were enumerated on plate count agar supplemented with reconstituted skim milk at $10 \%$ and tributyrin agar respectively, after incubation at $32^{\circ} \mathrm{C}$ for $72 \mathrm{~h}$. Moulds and yeasts were determined on potato dextrose agar acidified with $10 \mathrm{~mL} / \mathrm{L}$ of $10 \%(\mathrm{w} / \mathrm{v})$ sterile tartaric acid incubated at $25^{\circ} \mathrm{C}$ for 5 days. Halotolerants were enumerated using mannitol salt agar at $32^{\circ} \mathrm{C}$ for $72 \mathrm{~h}$. Fecal and total coliforms were enumerated on violet red bile agar after incubation for $24 \mathrm{~h}$ at 44 and $32^{\circ} \mathrm{C}$, respectively. The surface spread technique was used for psychrotrophics, proteolytic and lipolytic organisms, halotolerants and for moulds and yeasts. The pour plate technique was used for TVC. The pour plate and overlay technique was used for lactobacilli, lactococci and fecal and total coliforms. After incubation, plates with 25-250 colonies were counted. All microbiological analysis were performed according to American Public Health Association (1). All media were from Oxoid (Unipath Ltd., Basingstoke, England).

\section{Isolation procedure and identification of lactic bacteria}

For all sampling points, plates corresponding to dilutions of 25-50 colonies/plate were selected from M17 and Rogosa media. From each of these plates five to eight colonies, representing all different morphologies, were then picked at random. The isolates were purified by 4 cycles of subcultures on MRS broth and agar at $30^{\circ} \mathrm{C}$ and stored in MRS broth containing $20 \%(\mathrm{v} / \mathrm{v})$ glycerol, at $-12^{\circ} \mathrm{C}$. Isolates were identified according to the criteria of Sharpe (28). In order to identify the genera several tests were applied: Gram staining, microscopic examination, catalase, growth at 10 and $45^{\circ} \mathrm{C}$ in MRS broth, salt tolerance (6.5\% NaCl in MRS broth), L-arginine hydrolysis and production of carbon dioxide from glucose. These tests were performed according to techniques described by Harrigan and McCance (16). 


\section{Physicochemical analysis}

The $\mathrm{pH}$ of the milk was measured directly with a pHmeter DM 20 (Digimed, Brazil) and the titratable acidity of milk was measured following the method 947.05 (3). The $\mathrm{pH}$ and titratable acidity of curd and cheese were measured as described by the methods 14.022 (2) and 920.124 (4), respectively. The moisture content and the water activity $\left(\mathrm{a}_{\mathrm{w}}\right)$ were determined instrumentally using a MA30 Moisture Analyzer (Sartorius, Germany) and an Aqua Lab CX-2 Water Activity System (Decagon Devices, USA), respectively. The $\mathrm{NaCl}$ content was determined according to method 935.43 (4). All analyses were carried out in duplicates.

\section{Statistical analysis}

Plate count data were transformed into logarithms prior to statistical treatment. Statistical analysis was performed using the SPSS software (29). Differences between the treatment means were compared at the 5\% level of significance. Data were subjected to analysis of variance (ANOVA) in order to assess the statistical significance of the effect of ripening time in the microbial counts and physicochemical parameters and the Tukey's or Dunnet T3 test were performed for comparison of means. Comparison of means by the $t$ test was used to determine the influence of the season of the year on the microbiological and physicochemical characteristics of cheese. Statistical correlations between log counts of the major microbial groups and physicochemical parameters investigated were assessed by the Pearson's correlation coefficient.

\section{RESULTS AND DISCUSSION}

\section{Changes in the microbial groups counts during ripening}

The counts of the different microbial groups investigated during the manufacturing and ripening of Serrano cheese are shown in Table 1.

An increase of around $1 \log$ was found from milk to curd in the counts of the different microbial groups investigated, except for filamentous fungi. This increase in the number of microorganisms is a normal phenomenon in the manufacturing of cheese and it results partially from microbial multiplication during curdling and partially from the physical retention of these microorganisms in the curd when whey is run off. The low increase

Table 1. Changes in the counts (log cfu/g) of the microbial groups of Serrano cheese during manufacturing and ripening in summer ${ }^{1}$ and in winter ${ }^{1}$.

\begin{tabular}{|c|c|c|c|c|c|c|c|c|}
\hline \multirow{2}{*}{$\begin{array}{l}\text { Microbial } \\
\text { Group } \\
(\log \text { cfu/g) }\end{array}$} & \multirow[b]{2}{*}{ Season } & \multirow[b]{2}{*}{ Milk } & \multirow{2}{*}{ Curd } & \multicolumn{5}{|c|}{ Ripening time (days) } \\
\hline & & & & 7 & 14 & 28 & 42 & 60 \\
\hline \multirow{2}{*}{$\mathrm{T}$} & Summer & $6.07 \pm 0.64^{\mathrm{a}}$ & $7.60 \pm 0.90^{b}$ & $9.32 \pm 0.05^{\mathrm{c}}$ & $9.00 \pm 0.05^{\mathrm{bc}}$ & $8.57 \pm 0.11^{\mathrm{bc}}$ & $8.36 \pm 0.44^{\mathrm{bc}}$ & $7.71 \pm 0.62^{b}$ \\
\hline & Winter & $5.70 \pm 0.77^{\mathrm{a}}$ & $7.40 \pm 1.15^{\mathrm{ab}}$ & $9.19 \pm 0.36^{c}$ & $9.12 \pm 0.24^{\mathrm{c}}$ & $8.65 \pm 0.28^{\mathrm{bc}}$ & $7.98 \pm 0.43^{b c}$ & $7.56 \pm 0.21^{\mathrm{bc}}$ \\
\hline \multirow{2}{*}{ Psychrotrophic } & Summer & $6.00 \pm 1.09^{\mathrm{ab}}$ & $7.35 \pm 0.70^{\mathrm{ab}}$ & $8.06 \pm 0.09^{b}$ & $7.80 \pm 0.39^{\mathrm{b}}$ & $6.90 \pm 0.78^{\mathrm{ab}}$ & $6.72 \pm 1.34^{\mathrm{ab}}$ & $4.94 \pm 1.62^{\mathrm{a}}$ \\
\hline & Winter & $5.49 \pm 0.95^{\mathrm{a}}$ & $6.49 \pm 0.54^{\mathrm{ab}}$ & $8.26 \pm 0.52^{\mathrm{c}}$ & $8.15 \pm 0.51^{\mathrm{c}}$ & $8.10 \pm 0.34^{c}$ & $7.64 \pm 0.34^{\mathrm{bc}}$ & $7.02 \pm 0.56^{\mathrm{abc}}$ \\
\hline \multirow{2}{*}{ Proteolytic } & Summer & $5.03 \pm 0.33^{\mathrm{a}}$ & $5.91 \pm 0.27^{\mathrm{ab}}$ & $7.12 \pm 1.40^{\mathrm{ab}}$ & $8.09 \pm 0.34^{\mathrm{b}}$ & $7.50 \pm 0.88^{b}$ & $7.17 \pm 0.58^{\mathrm{ab}}$ & $7.10 \pm 1.18^{\mathrm{ab}}$ \\
\hline & Winter & $4.88 \pm 0.72$ & $5.97 \pm 0.59$ & $7.09 \pm 2.27$ & $9.05 \pm 0.34$ & $8.67 \pm 0.16$ & $7.82 \pm 0.79$ & $7.86 \pm 0.75$ \\
\hline \multirow{2}{*}{ Lipolytic } & Summer & $3.94 \pm 0.92^{\mathrm{a}}$ & $5.18 \pm 0.57^{\mathrm{a}}$ & $6.50 \pm 0.74^{\mathrm{a}}$ & $6.59 \pm 1.67^{\mathrm{a}}$ & $6.43 \pm 0.99^{\mathrm{a}}$ & $5.57 \pm 0.74^{\mathrm{a}}$ & $5.50 \pm 0.93^{\mathrm{a}}$ \\
\hline & Winter & $4.94 \pm 0.76^{\mathrm{a}}$ & $6.15 \pm 0.50^{\mathrm{a}}$ & $6.16 \pm 0.60^{\mathrm{a}}$ & $6.26 \pm 0.81^{\mathrm{a}}$ & $5.13 \pm 0.64^{\mathrm{a}}$ & $5.30 \pm 0.84^{\mathrm{a}}$ & $4.68 \pm 1.46^{\mathrm{a}}$ \\
\hline \multirow{2}{*}{ Lactococci } & Summer & $5.84 \pm 0.66^{\mathrm{a}}$ & $7.60 \pm 0.84^{b}$ & $9.31 \pm 0.03^{\mathrm{c}}$ & $8.92 \pm 0.10^{\mathrm{bc}}$ & $8.42 \pm 0.20^{\mathrm{bc}}$ & $8.17 \pm 0.57^{b c}$ & $8.00 \pm 0.31^{b c}$ \\
\hline & Winter & $5.63 \pm 0.48$ & $7.32 \pm 1.31$ & $9.14 \pm 0.30$ & $9.07 \pm 0.43$ & $8.29 \pm 0.14$ & $7.70 \pm 0.38$ & $7.68 \pm 0.31$ \\
\hline \multirow{2}{*}{ Lactobacilli } & Summer & $4.32 \pm 1.43^{\mathrm{a}}$ & $5.62 \pm 0.89^{\mathrm{a}}$ & $8.38 \pm 0.63^{b}$ & $8.34 \pm 0.38^{b}$ & $8.39 \pm 0.21^{\mathrm{b}}$ & $8.27 \pm 0.27^{b}$ & $8.15 \pm 0.04^{b}$ \\
\hline & Winter & $3.46 \pm 1.11$ & $4.16 \pm 1.41$ & $7.24 \pm 1.71$ & $7.77 \pm 0.95$ & $7.98 \pm 0.83$ & $7.91 \pm 0.37$ & $7.92 \pm 0.21$ \\
\hline \multirow{2}{*}{ Halotolerant } & Summer & $5.26 \pm 0.57^{\mathrm{ab}}$ & $6.42 \pm 0.56^{\mathrm{b}}$ & $6.52 \pm 0.56^{\mathrm{b}}$ & $5.72 \pm 0.01^{\mathrm{ab}}$ & $5.24 \pm 0.42^{\mathrm{ab}}$ & $4.63 \pm 0.78^{\mathrm{a}}$ & $4.64 \pm 0.79^{\mathrm{a}}$ \\
\hline & Winter & $4.55 \pm 0.58^{\mathrm{a}}$ & $6.13 \pm 0.67^{b}$ & $6.74 \pm 0.14^{\mathrm{b}}$ & $6.37 \pm 0.57^{b}$ & $6.09 \pm 0.43^{b}$ & $6.15 \pm 0.26^{\mathrm{b}}$ & $6.02 \pm 0.03^{b}$ \\
\hline \multirow{2}{*}{ Moulds } & Summer & $2.49 \pm 0.27^{\mathrm{a}}$ & $2.53 \pm 0.21^{\mathrm{ab}}$ & $4.70 \pm 0.30^{\mathrm{b}}$ & $3.67 \pm 0.06^{\mathrm{ab}}$ & $2.93 \pm 0.83^{\mathrm{ab}}$ & $1.20 \pm 2.08^{\mathrm{a}}$ & $1.94 \pm 1.68^{\mathrm{a}}$ \\
\hline & Winter & $1.49 \pm 1.31^{\mathrm{a}}$ & $1.49 \pm 1.29^{\mathrm{a}}$ & $2.52 \pm 0.91^{\mathrm{a}}$ & $2.64 \pm 0.59^{\mathrm{a}}$ & $1.43 \pm 1.25^{\mathrm{a}}$ & $1.33 \pm 1.15^{\mathrm{a}}$ & $0.67 \pm 1.15^{\mathrm{a}}$ \\
\hline \multirow{2}{*}{ Yeasts } & Summer & $3.03 \pm 0.77^{\mathrm{a}}$ & $4.42 \pm 0.76^{\mathrm{ab}}$ & $6.04 \pm 0.27^{b}$ & $4.81 \pm 0.70^{\mathrm{ab}}$ & $4.80 \pm 0.55^{\mathrm{ab}}$ & $4.24 \pm 0.70^{\mathrm{ab}}$ & $3.72 \pm 0.66^{\mathrm{a}}$ \\
\hline & Winter & $3.37 \pm 0.63^{\mathrm{a}}$ & $4.59 \pm 0.37^{\mathrm{a}}$ & $5.51 \pm 1.04^{\mathrm{a}}$ & $4.59 \pm 0.84^{\mathrm{a}}$ & $4.63 \pm 0.80^{\mathrm{a}}$ & $4.08 \pm 1.55^{\mathrm{a}}$ & $4.07 \pm 1.17^{\mathrm{a}}$ \\
\hline \multirow{2}{*}{ Total Coliforms } & Summer & $4.03 \pm 1.34 \mathrm{ab}$ & $5.57 \pm 0.86^{\mathrm{b}}$ & $5.76 \pm 1.18^{b}$ & $5.45 \pm 1.33^{\mathrm{b}}$ & $4.07 \pm 2.37^{\mathrm{ab}}$ & $3.18 \pm 2.37^{\mathrm{ab}}$ & $0.57 \pm 0.88^{\mathrm{a}}$ \\
\hline & Winter & $3.54 \pm 0.96^{\mathrm{a}}$ & $4.84 \pm 0.82^{\mathrm{a}}$ & $4.98 \pm 1.27^{\mathrm{a}}$ & $3.65 \pm 2.14^{\mathrm{a}}$ & $3.13 \pm 3.11^{\mathrm{a}}$ & $2.74 \pm 3.00^{\mathrm{a}}$ & $3.01 \pm 2.98^{\mathrm{a}}$ \\
\hline \multirow{2}{*}{ Fecal Coliforms } & summer & $3.13 \pm 1.00^{\mathrm{ab}}$ & $4.27 \pm 0.54^{\mathrm{ab}}$ & $5.59 \pm 1.24^{\mathrm{b}}$ & $5.29 \pm 1.26^{\mathrm{b}}$ & $4.00 \pm 2.37^{\mathrm{ab}}$ & $2.69 \pm 2.69^{\mathrm{ab}}$ & $<10^{\mathrm{a}}$ \\
\hline & winter & $1.75 \pm 0.14^{\mathrm{a}}$ & $3.09 \pm 0.61^{\mathrm{a}}$ & $3.92 \pm 1.15^{\mathrm{a}}$ & $2.44 \pm 2.79^{\mathrm{a}}$ & $2.34 \pm 2.50^{\mathrm{a}}$ & $2.08 \pm 2.15^{\mathrm{a}}$ & $2.18 \pm 2.29^{\mathrm{a}}$ \\
\hline
\end{tabular}

${ }^{1}$ Data are the average values \pm standard deviation of three batches; ${ }^{2}$ Total viable counts; ${ }^{\text {acc }}$ Means in the same row with different superscripts differ $(\mathrm{P}<0.05)$. 
in the counts of all microbial groups of Serrano cheese may be explained by the short time interval between the collection of milk and curd samples (approximately $1.5 \mathrm{~h}$ ), in which microbial multiplication is minimum. According to Tatini et al. (30), the physical retention of microorganisms in the curd allows for the 1 log increase in the counts, the remaining being due to microbial multiplication. For most microbial groups maximum counts were attained after 1 week of ripening, both in Summer and winter.

Significant differences in the counts of halotolerants and moulds were only detected in association to the season in which the cheeses were manufactured and ripened. For moulds, an increase in the counts was observed in the Summer production when compared to the winter, perhaps due to lower temperatures, which decreased the growth rate of this microbial population. For halotolerants a more pronounced decrease in Summer counts was observed, possibly due to environmental conditions, which is in agreement with the high coefficient of correlation $(r=0.732)$ between $\mathrm{a}_{\mathrm{w}}$ and halotolerants in this season.

In the raw milk mean counts of 6.07 and $5.70 \mathrm{log}$ were achieved for TVC. These high counts are likely to stem from poor hygiene conditions during milking and are similar to those found in milk used for the production of other cheeses $(7,11,13,24)$ but lower than those determined in milk used in the manufacturing of Tafi (10) and León cheese (21). The number of CFU increased during the first week of ripening, achieving counts around 9.2-9.3 log, which, despite being higher than those found for Ulloa cheese (24), are similar to counts found for other varieties $(7,8,10,21,27)$. According to Kosikowski (19), values of 9 log are normal in cheese produced with raw milk. The coefficients of correlation found between $\mathrm{pH}$ values and the TVC in Summer ( $\mathrm{r}=-0.819)$ and winter $(\mathrm{r}=-0.827)$ suggest that this microflora may be comprised mainly of acid-tolerant microorganisms, as suggests correlations found between these counts and the titratable acid values ( $\mathrm{r}=0.607$ and $\mathrm{r}=0.647$, respectively).

The psychrotrophic counts in milk, 6.0 and $5.49 \mathrm{log}$, are similar to those found by other authors $(13,21)$. A significant increase was observed in the number of these microorganisms in milk until the first week of ripening, attaining values similar to those of San Simón (13) and León (21) cheeses. From the maximum count achieved at the $7^{\text {th }}$ day, a constant drop-off was observed until the end of the 60-day period. However, this reduction was more pronounced in Summer $(3 \mathrm{log})$ in comparison with winter $(1 \log )$, possibly due to environmental conditions, which contributed to a quicker decrease in this microbial population; this is in agreement with the coefficient of correlation between $\mathrm{a}_{\mathrm{w}}$ and these microorganisms in Summer $(\mathrm{r}=0.548)$. The high amount of psychrotrophics in Serrano cheese represents a potential risk of deterioration of this product. This problem becomes even more important as most cheeses are sold within 30 days of production and consumers store them at refrigeration temperatures. There is a significant difference between the psychrotrophic counts in the 60-day cheese and that of younger cheeses showing that a 2-month ripening period is the key to a reduction of these counts.

The proteolytic counts were higher than the lipolytics, this may be an indication that proteolytic activity is greater than lipolytic activity in this cheese, which is common in this kind of short ripening period cheese (17). The coefficients of correlation attained between the titratable acidity values and the proteolytic counts in Summer $(r=0.733)$ and in winter $(r=0.675)$ suggest that this population may be mainly comprised of acid-tolerant microorganisms. The correlations obtained between these counts and the $\mathrm{pH}$ values of Summer samples $(\mathrm{r}=-0.758)$ and winter samples $(\mathrm{r}=-0.701)$ are in accordance with this hypothesis.

The counts of lactococci of the milk until the cheeses at 2 weeks were $10^{1}$ to $10^{3}$ times higher than those of lactobacilli, both being similar in the following stages due to a higher death rate of the lactococci population during the final phase. The same phenomenon was observed by Fontán et al. (13). Ordóñez and Burgos (24) observed an increase of lactobacilli during the ripening of Ulloa cheese and Tornadijo et al. (31) found that lactobacilli were the prevalent microbial group in the late ripening stages of Armada cheese. According to Peterson et al. (25), during the fermentative process of cheese the formation of several metabolites, such as lactate, citratre, glycerol, and amino acids, among others, which are better utilized by lactobacilli, takes place.

The halotolerant microflora found in milk and cheese (5-6 $\log$ ) were similar to those of other cheese varieties, such as Casar de Cáceres (26), Arzúa (7), Tetilla (22) and San Simón (13). For Léon (21), Cebreiro (8), Afuega'l Pitu (9) and Anevato (17) cheeses, counts by 2-3 log units lower were found. These differences were probably due to $\mathrm{pH}$ variations, since these microorganisms are acid-sensitive. In this cheese and others that had a similar halotolerant microorganisms count, the $\mathrm{pH}$ was maintained around 5.0, favoring the development of this population. As these microorganisms were found in significant levels they might contribute to the ripening process to some extent, through their lipolytic and proteolytic activities, playing a role in the change in texture and aroma development. However, as halotolerants include mainly the Micrococcaceae family, which is comprised of the genera Micrococcus and Staphylococcus, one must pay heed to this result, since there is a potential risk for consumer health if enterotoxin-producing coagulase-positive Staphylococcus aureus are present.

The counts of moulds and yeasts during ripening were similar to those found in other cheeses, such as Tetilla (22) and Arzúa (7). As ripening advances, there is an increase in cheese matrix compaction, which reduces the diffusion of the oxygen required for the multiplication of these microbial populations.

The high amount of total and fecal coliforms detected in raw milk is again an indication of the low hygienic quality of the raw material used in the manufacturing of this cheese. These microbial groups did not present significant variations in winter while, in Summer, the time of ripening had a significant influence over the 
counts of these populations and the 60-day ripening time was important for their reduction. An important feature regarding the sanitary-hygienic aspect is the absence of fecal coliforms in the end of the ripening process in Summer. The coefficients of correlation among the counts of total coliforms, $\mathrm{a}_{\mathrm{w}}(\mathrm{r}=0.527)$ and moisture content $(\mathrm{r}=0.569)$ show that these parameters influenced the decrease of this population in Summer. Total coliforms were not detected in Tafi cheese after 30 days of ripening due to low $\mathrm{a}_{\mathrm{w}}$ (10). The higher temperatures at the maturation room in this season also showed influence over the coliform population. The 60-day old Manchego cheese ripened at $10^{\circ} \mathrm{C}$ had a count of 2.07 and $2.24 \log$ for total and fecal coliforms, respectively; however, when ripening took place at $20^{\circ} \mathrm{C}$, neither population was detected (23). Total coliforms had a higher decrease rate in La Serena cheeses ripened at $16.9^{\circ} \mathrm{C}$ than in those ripened at $13.6^{\circ} \mathrm{C}(12)$. The high levels of total and fecal coliforms may be the main cause for the formation of holes in Serrano cheese.

\section{Lactic acid bacteria isolated during ripening}

Of a total of 484 isolates in cheese, 431 were identified as LAB. Fig. 1 shows the distribution rate of lactic bacteria identified throughout the process of manufacturing and ripening.

The lactobacilli were the most abundant lactic bacteria, followed by enterococci and lactococci. The lactobacilli prevailed throughout the manufacturing and ripening process, especially in the late steps of the process, suggesting that these microorganisms play an important role in the production of this cheese and could be part of its lactic culture. Maybe the low ratio of lactococci and leuconostoc in the lactic isolates stems from adding salt to milk during cheese preparation, inhibiting the growth of these microorganisms. The low amount of

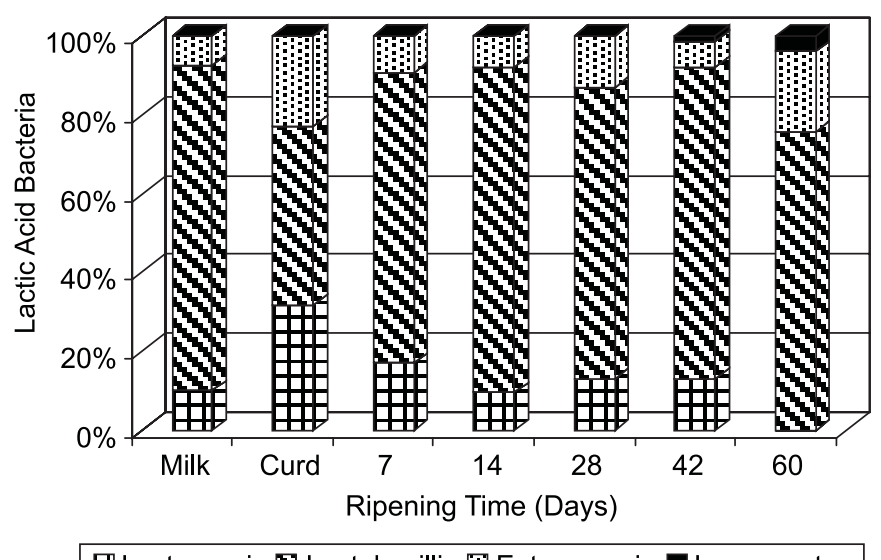

\#Lactococci Lactobacilli Enterococci Leuconostoc

Figure 1. Evolution of genera of LAB (431 strains) during manufacturing and ripening of Serrano cheese. Percentage of strains of each genera isolated from M17 and Rogosa at each stage.

heterofermentative lactobacilli and Leuconostoc spp. supports the hypothesis that the great number of holes in this cheese results from the high count of coliforms.

\section{Changes in the physicochemical characteristics during ripening}

Table 2 shows the evolution of the physicochemical characteristics investigated during the manufacturing and ripening of Serrano cheese.

The $\mathrm{pH}$ around $6.7 \mathrm{in}$ raw milk used for the manufacturing of this cheese is similar to that of milk used for the production of other cheeses made from bovine milk $(7,9,11,13,21)$. During the

Table 2. Changes in the physicochemical characteristics of Serrano cheese during manufacturing and ripening in the summer ${ }^{1}$ and in the winter ${ }^{1}$.

\begin{tabular}{|c|c|c|c|c|c|c|c|c|}
\hline \multirow{2}{*}{ Characteristic } & \multirow{2}{*}{ Season } & \multirow{2}{*}{ Milk } & \multirow{2}{*}{ Curd } & \multicolumn{5}{|c|}{ Ripening time (days) } \\
\hline & & & & 7 & 14 & 28 & 42 & 60 \\
\hline \multirow{2}{*}{$\mathrm{pH}$} & summer & $6.71 \pm 0.05^{\mathrm{c}}$ & $6.36 \pm 0.19^{\mathrm{bc}}$ & $5.33 \pm 0.09^{\mathrm{a}}$ & $5.52 \pm 0.05^{\mathrm{a}}$ & $5.80 \pm 0.36^{\mathrm{ab}}$ & $5.75 \pm 0.33^{\mathrm{ab}}$ & $5.66 \pm 0.23^{\mathrm{a}}$ \\
\hline & winter & $6.66 \pm 0.04$ & $6.29 \pm 0.56$ & $5.1 \pm 0.21$ & $5.20 \pm 0.25$ & $5.24 \pm 0.19$ & $5.30 \pm 0.23$ & $5.30 \pm 0.19$ \\
\hline \multirow{2}{*}{$\begin{array}{l}\text { Titratable } \\
\text { acidity }^{2}\end{array}$} & summer & $0.2 \pm 0.0^{\mathrm{a}}$ & $0.2 \pm 0.0^{\mathrm{a}}$ & $1.1 \pm 0.1^{\mathrm{b}}$ & $1.1 \pm 0.2^{\mathrm{b}}$ & $0.9 \pm 0.3^{\mathrm{ab}}$ & $1.3 \pm 0.5^{b}$ & $1.4 \pm 0.4^{\mathrm{b}}$ \\
\hline & winter & $0.2 \pm 0.0^{\mathrm{a}}$ & $0.3 \pm 0.2^{\mathrm{ab}}$ & $0.9 \pm 0.2^{\mathrm{bc}}$ & $0.9 \pm 0.3^{c}$ & $1.0 \pm 0.3^{\mathrm{c}}$ & $0.9 \pm 0.3^{\mathrm{bc}}$ & $1.0 \pm 0.2^{\mathrm{c}}$ \\
\hline \multirow{2}{*}{ Moisture (\%) } & summer & - & $50.78 \pm 1.17^{\mathrm{d}}$ & $40.52 \pm 4.73^{c}$ & $36.85 \pm 2.26^{\mathrm{bc}}$ & $36.63 \pm 2.82^{b c}$ & $29.56 \pm 2.46^{\mathrm{ab}}$ & $27.57 \pm 0.72^{\mathrm{a}}$ \\
\hline & winter & - & $57.30 \pm 3.76^{\mathrm{d}}$ & $45.37 \pm 1.71^{\mathrm{c}}$ & $43.34 \pm 0.88^{\mathrm{bc}}$ & $39.81 \pm 0.73^{\mathrm{bc}}$ & $36.80 \pm 1.06^{\mathrm{ab}}$ & $32.98 \pm 4.16^{\mathrm{a}}$ \\
\hline \multirow[b]{2}{*}{$a_{w}$} & summer & - & $0.987 \pm 0.003^{\mathrm{c}}$ & $0.97 \pm 0.004^{\mathrm{bc}}$ & $0.962 \pm 0.006^{\mathrm{b}}$ & $0.953 \pm 0.007^{\mathrm{ab}}$ & $0.939 \pm 0.010^{\mathrm{a}}$ & $0.935 \pm 0.007^{\mathrm{a}}$ \\
\hline & winter & - & $0.984 \pm 0.005^{\mathrm{b}}$ & $0.970 \pm 0.004^{\mathrm{ab}}$ & $0.967 \pm 0.003^{\mathrm{ab}}$ & $0.966 \pm 0.006^{\mathrm{ab}}$ & $0.957 \pm 0.008^{\mathrm{a}}$ & $0.954 \pm 0.012^{\mathrm{a}}$ \\
\hline \multirow{2}{*}{$\mathrm{NaCl}(\%$ of $\mathrm{TS})$} & summer & - & $1.4 \pm 0.6^{\mathrm{a}}$ & $1.2 \pm 0.4^{\mathrm{a}}$ & $1.3 \pm 0.4^{\mathrm{a}}$ & $1.6 \pm 1.0^{\mathrm{a}}$ & $1.4 \pm 0.6^{\mathrm{a}}$ & $1.4 \pm 0.6^{\mathrm{a}}$ \\
\hline & winter & - & $1.3 \pm 1.5^{\mathrm{a}}$ & $1.6 \pm 0.9^{\mathrm{a}}$ & $1.3 \pm 0.7^{\mathrm{a}}$ & $1.5 \pm 0.8^{\mathrm{a}}$ & $1.7 \pm 0.9^{\mathrm{a}}$ & $1.5 \pm 0.8^{\mathrm{a}}$ \\
\hline \multirow{2}{*}{$\begin{array}{c}\mathrm{NaCl} \text { in } \\
\text { moisture(\%) }\end{array}$} & summer & - & $1.4 \pm 0.6^{\mathrm{a}}$ & $1.9 \pm 0.9^{\mathrm{a}}$ & $2.3 \pm 0.9^{\mathrm{a}}$ & $2.6 \pm 1.3^{\mathrm{a}}$ & $3.1 \pm 1.3^{\mathrm{a}}$ & $3.4 \pm 1.3^{\mathrm{a}}$ \\
\hline & winter & - & $0.9 \pm 0.9^{\mathrm{a}}$ & $1.8 \pm 1.0^{\mathrm{a}}$ & $1.7 \pm 1.0^{\mathrm{a}}$ & $2.2 \pm 1.1^{\mathrm{a}}$ & $2.8 \pm 1.6^{\mathrm{a}}$ & $3.1 \pm 1.8^{\mathrm{a}}$ \\
\hline
\end{tabular}

${ }^{1}$ Data are the average values \pm standard deviation of three batches; ${ }^{2}$ Expressed in $\%$ of lactic acid;

${ }^{\mathrm{a}-\mathrm{c}}$ Means in the same row with different superscripts differ significantly $(\mathrm{P}<0.05)$. 
curdling process, the $\mathrm{pH}$ decreased significantly during the first week of ripening, when it hit the lowest values in the whole process; 5.3 in Summer and 5.1 in winter. This decrease by approximately 1.5 units is a consequence of the lactic acid production by lactic bacteria. Manchego cheese ripened at $10^{\circ} \mathrm{C}$ and $20^{\circ} \mathrm{C}$ had $\mathrm{pH}$ values of 5.07 and 5.28 , respectively (23). The significant increase in $\mathrm{pH}$ between the first and the fourth ripening week in Summer result from the metabolic activity of mould and yeast, which use lactic acid as a source of carbon, and/or the proteolytic process that releases great amounts of nitrogenated alkaline compounds (31). In winter, the $\mathrm{pH}$ did not present significant variations after the $7^{\text {th }}$ day of ripening. The lower temperatures of this period are likely to have reduced the intensity of biochemical reactions, resulting in a constant $\mathrm{pH}$ until the end of the process. The $\mathrm{pH}$ values during the ripening, mainly in Summer, favored the action of microbial proteases, which present maximum activity in the $\mathrm{pH}$ interval between 5.5-6.5 (6).

The more pronounced decrease in $\mathrm{a}_{\mathrm{w}}$ in Summer is probably due to the greater water evaporation and hydrolysis of proteins during ripening in this hotter temperature period. The mean $a_{w}$ values in the end of ripening was not low enough in order to control the growth of most microbial groups analyzed. No significant variation in $\mathrm{a}_{\mathrm{w}}$ was detected between season productions. Cheese moisture, however, significantly varied between the two periods. Therefore, the reduction was better evidenced in the samples ripened in Summer, due to high temperature and lower relative air humidity in the maturation room, which cause an extensive dehydration. Margolles et al. (20) analyzed the effect of climatic conditions of the different seasons on the features of some Spanish cheeses and observed that only cheese moisture varied significantly, with the higher values detected in winter.

The low concentration of $\mathrm{NaCl}$ at the watery phase during the ripening process was not enough to inhibit the growth of microbial groups.

The evolution that physicochemical parameters undergo with the ripening of Serrano cheese does not produce markedly antagonistic conditions for any of the microbial groups investigated. Therefore, the progressive reduction of the microorganisms in the core of the cheese is not a consequence of a single inhibitory effect, but rather the combination of several factors.

Although the microbiologial countings and the main physico chemical caractheristics of Serrano cheese have shown to vary significantly during ripening, the production itself did not present any important variations considering the season of the year, except for halotorant counts, moulds and moisture content of cheeses.

\section{ACKNOWLEDGEMENTS}

The authors whish to thank CNPq, CAPES and FAPERGS for their financial support.

\section{RESUMO}

\section{Evolução das características microbiológicas e físico-químicas durante a elaboração e maturação do queijo Serrano}

As variações da microbiota de seis bateladas do queijo Serrano (3 maturadas no verão e 3 maturadas no inverno) foram estudadas durante a produção e maturação, com o objetivo de caracterizálo microbiologicamente. Este queijo é tradicionalmente elaborado com leite cru, sem a adição de cultura lática, por produtores rurais do sul do Brasil. Vários grupos microbianos foram enumerados no leite, na coalhada e em diferentes estágios ao longo dos 60 dias de maturação. Também foram investigados alguns parâmetros físico-químicos, tais como $\mathrm{pH}$, acidez titulável, atividade de água, umidade e teor de $\mathrm{NaCl}$. Determinaram-se os coeficientes de correlação entre os valores desses parâmetros e as contagens dos microrganismos ao longo da maturação. A influência da estação do ano também foi estudada. Os resultados demonstraram que a microbiota e as características físico-químicas do queijo Serrano apresentaram variações significativas durante o período de maturação de 60 dias, principalmente no verão. A maioria dos grupos microbianos atingiram suas contagens máximas no queijo aos 7 dias, diminuindo progressivamente até o final da maturação. $\mathrm{O}$ aumento nas contagens durante a primeira semana de maturação foi acompanhado por um declínio acentuado no valor do $\mathrm{pH}$, devido à produção de ácido pelos microrganismos. As bactérias láticas constituíram-se no principal grupo microbiano do queijo Serrano e suas contagens foram similares as de microrganismos viáveis totais em todos os pontos amostrados. O grande número de lactobacilos durante a elaboração e maturação do queijo sugere que estes microrganismos possam ter um papel importante na produção deste queijo. Em conclusão, o trabalho aponta a importância de um tempo de maturação superior a trinta dias como fator de estabilização microbiológica deste produto artesanal, bem como o fato de ser um produto bastante homogêneo quanto às suas características físico-químicas e microbiológicas, independente da estação do ano, exceto para as contagens de halotolerantes e de bolores e do teor de umidade, que apresentaram diferenças significativas entre o verão e o inverno.

Palavras-chave: queijo Serrano, maturação do queijo, microbiologia de alimentos, bactérias láticas.

\section{REFERENCES}

1. American Public Health Association. Standard Methods for the Examination of Dairy Products. APHA, Washington, 1993.

2. Association of Official Analytical Chemists. Official Methods of Analysis. AOAC, Washington, 1980.

3. Association of Official Analytical Chemists. Official Methods of Analysis. AOAC, Arlington, 1990. 
4. Association of Official Analytical Chemists. Official Methods of Analysis. AOAC, Maryland, 1996.

5. Brasil. Portaria n. 146, de 7 de março de 1996. Aprova Regulamento Técnico de Identidade e Qualidade de Queijos. Diário Oficial, Brasília, 11 de março de 1996, seção 1, p.3977-3979.

6. Choisy, C.; Desmazeaud, M.; Gripon, J.C.; Lamberet, G.; Lenoir, J.; Tourneur, C. Los fenómenos microbiológicos y enzimáticos y la bioquímica del afinado. In: Eck, A.(ed). El Queso. Omega, Barcelona, 1990.

7. Centeno, J.A.; Rodriguez-Otero, J.L.; Cepeda, A. Microbiological study of Arzúa cheese (NW Spain) throughout cheesemaking and ripening. J. Food Safety, 14:229-241, 1994.

8. Centeno, J.A.; Menéndez, S.; Rodríguez-Otero, J.L. Main microbial flora present as natural starters in Cebreiro raw cow's-milk cheese (Northwest Spain). Int. J. Food Microbiol., 33:307-313, 1996.

9. Cuesta, P.; Fernández-García, E.; González de Llano, D.; Montilla, A.; Rodríguez, A. Evolution of the microbiological and biochemical characteristics of Afuega'l Pitu cheese during ripening. J. Dairy Science, 79:1693-1698, 1996.

10. De Giori, G.S.; Valdéz, G.F.; Holgado, A.P.R.; Oliver, G. Microflora of Tafí Cheese: changes during manufacture and maturation. J. Food Prot., 46:518-521, 1983.

11. Estepar, J.; Sánchez, M.M.; Alonso, L.; Mayo, B. Biochemical and microbiological characterization of artisanal "Peñamellera" cheese: analysis of its indigenous lactic acid bacteria. Int. Dairy J., 9:737746, 1999.

12. Fernandez del Pozo, B.; Gaya, P.; Medina, M.; Rodríguez-Marín, M.A.; Nuñez, M. Changes in the microflora of La Serena ewes' milk cheese during ripening. J. Dairy Res., 55:449-455, 1988.

13. Fontán, M.C.G.; Franco, I.; Prieto, B.; Tornadijo, M.E.; Carballo, J. Microbiological changes in "San Simón" cheese throughout ripening and its relationship with physico-chemical parameters. Food Microbiol., 18:25-33, 2001.

14. Gomes, M.I.F.V.; Bonassi, I.A. Aspecto microbiológico do queijo tipo Minas Prensado. Rev. Inst. Latic. "Cândido Tostes", 50:23-26, 1995.

15. Gomes, M.I.F.V.; Bonassi, I.A. Evolução da microbiota durante a cura do queijo Minas Padronizado. Ciênc. Tecnol. Aliment., 16:179$183,1996$.

16. Harrigan, W.F.; McCance, M.E. Biochemical tests for bacteria. In: Harrigan, W.F.; McCance, M.E.(eds). Laboratory methods in foods and dairy microbiology. Academic Press, London, 1976, p.66-81.
17. Hatzikamari, M.; Litopoulou-Tzanetaki, E.; Tzanetakis, N. Microbiological characteristics of Anevato: a traditional Greek cheese. J. Appl. Microbiol., 87:595-601, 1999.

18. International Dairy Federation. Milk and milk products. Methods of sampling. IDF, Brussels, 1985.

19. Kosikowski, F. Cheese and fermented milk foods. Brooktondale, New York, 1977.

20. Margolles, A.; Rodriguez, A.; Reyes-Gavilan, C.G. Some chemical and bacteriological characteristics of regional cheeses from Asturias, Spain. J. Food Prot., 59:509-515, 1996.

21. Medina, M.L.R.; Tornadijo, M.E.; Carballo, J.; Sarmiento, R.M. Microbiological study of León Raw Cow-Milk Cheese, a Spanish Craft Variety. J. Food Prot., 57:998-1006, 1995.

22. Menéndez, S.; Godínez, R.; Centeno, J.A.; Rodríguez-Otero, J.L. Microbiological, chemical and biochemical characteristics of "Tetilla" raw cows-milk cheese. Food Microbiol., 18:151-158, 2001.

23. Nuñez, M.; Gaya, P.; Medina, M. Influence of manufacturing and ripening conditions on the survival of Enterobacteriaceae in Manchego cheese. J. Dairy Sci., 68:794-800, 1985.

24. Ordónez, J.A.; Burgos, J. Étude de la variété de fromage "Ulloa". Le Lait, 57:150-163, 1977.

25. Peterson, S.D.; Marshall, R.T. Non starter lactobacilli in Cheddar Cheese. a review. J. Dairy Sci., 73:1395-1410, 1990.

26. Poullet, B.; Huertas, M.; Sánchez, A.; Cáceres, P.; Larriba, G. Microbial study of Casar de Cáceres cheese throughout ripening. J. Dairy Res., 58:231-238, 1991

27. Quinto, E.; Franco, C.; Rodríguez-Otero, J.L.; Fente, C.; Cepeda, A. Microbiological quality of Cebrero cheese from Northwest Spain. $J$. Food Safety, 14:1-8, 1994.

28. Sharpe, M.E. Identification of the lactic acid bacteria. In: Skinner, F.A.; Lovelock, D.W.(eds). Identification Methods for Microbiologist. 2.ed. Academic Press, London, 1979, p.233-259.

29. SPSS software. User's Guide, Release 8.0, SPSS Inc., Chicago, 1998.

30. Tatini, S.R.; Jezeski, J.J.; Morris, H.A. Production of staphylococcal enterotoxin A in Cheddar and Colby cheeses. J. Dairy Sci., 54:815$825,1971$.

31. Tornadijo, M.E.; Fresno, J.M.; Bernardo, A.; Sarmiento, R.M.; Carballo, J. Microbiological changes throughout the manufacturing and ripening of a Spanish goat's raw milk cheese (Armada variety). Lait, 75:551-570, 1995. 